\title{
Parcerias estratégicas no contexto da política exterior brasileira: implicações para o Mercosul $^{1}$
}

\author{
ALCIDES COSTA VAZ*
}

\section{Introdução}

A construção de parcerias pelo Brasil tem sido objeto de pouco estudo nos anos recentes, apesar da crescente importância que vem assumindo no contexto da política exterior brasileira enquanto forma de realizar objetivos e interesses no plano externo e de definir padrões de relacionamento com países individualmente e, também, com os principais blocos econômicos. O crescente leque de opções que o Brasil vem procurando explorar, no âmbito regional, como em outras áreas, não está desvinculado de sua projeção no Mercado Comum do Sul (Mercosul), acarretando, por conseguinte, oportunidades e também possíveis dificuldades no que se refere ao relacionamento nesse âmbito, notadamente, com a Argentina, e às vinculações externas do próprio Mercosul.

Com o propósito de analisar as implicações para o Mercosul do esforço brasileiro de construir parcerias internacionais, procuraremos, antes, contextualizálas historicamente, percorrendo distintos períodos da evolução da política externa brasileira para identificar a natureza das mesmas e caracterizar seu sentido de funcionalidade frente aos objetivos e prioridades estabelecidas em cada período. Isso se faz necessário não apenas para prover informações quanto aos antecedentes do esforço de construção de parcerias ora empreendido, mas, sobretudo, porque a política externa brasileira reflete, em sua evolução, um forte impulso de permanência, especialmente no que se refere à projeção de interesses do Estado. $\mathrm{O}$ entendimento quanto ao sentido de parcerias estratégicas a ser considerado na presente análise as associa à condição de relacionamento privilegiado, em nível bilateral, para a realização de interesses (não necessariamente comuns), tidos como importantes para consecução de objetivos internos e/ou externos de parte dos Estados que as constituem. Argumenta-se que a construção de parcerias, pelo Brasil, esteve sempre voltada para o acesso a recursos, insumos e oportunidades a serem canalizados 
para o processo de desenvolvimento, e que, nesse sentido, possui também funcionalidade para o fortalecimento do Mercosul, ainda que não o seja de forma automática e não exclua o risco de gerar áreas de divergência ou assintonia com seus sócios.

O texto está assim estruturado: na primeira parte, discute-se o caráter universalista da política externa como condicionante da construção de parcerias; na segunda, procede-se a uma breve análise retrospectiva de como as parcerias estratégicas vincularam-se, em distintos momentos, às prioridades definidas em sucessivos períodos da política externa brasileira a partir dos anos cinqüenta. A terceira parte enfoca o redirecionamento das parcerias estratégicas em razão das mudanças ocorridas no plano externo e internamente no Brasil, com a introdução de um novo modelo econômico a partir do início dos anos noventa; em seguida, são analisadas as prioridades da atual política externa brasileira e as implicações em termos de construção de parcerias internacionais e os desdobramentos destas para o Mercosul.

\section{1- Universalidade da política externa brasileira como âmbito da construção de parcerias estratégicas}

São recorrentes, no discurso diplomático e nas análises sobre a política externa brasileira, as alusões à sua universalidade. Esse caráter universalista associa-se às características territoriais e à diversidade étnica e cultural do país e exprime, segundo essa lógica, a pluralidade de interesses do Estado e da sociedade brasileira, as afinidades históricas e a decorrente diversidade de vínculos externos de natureza política, econômica e cultural, o que conduz à opção de não estabelecer alinhamentos automáticos, ainda mais em um cenário internacional marcado por elevado grau de incerteza quanto a sua evolução futura. Assim, e segundo o exChanceler Celso Amorim, "o Brasil, por suas dimensões, por sua complexidade, pelo seu tecido social, pela composição étnica e cultural de sua população, não cabe em nenhum bloco, político e econômico, ou em nenhuma área de influência" ${ }^{2}$. No sentido econômico, o universalismo associa-se ao grau de diversificação dos fluxos comerciais brasileiros em sua origem, procedência e composição, caracterizando o país como o que se convencionou denominar global trader ${ }^{3}$. No sentido político, exprime também o sentido de uma vocação orientada para uma presença ativa na cena internacional exercida nos diferentes foros multilaterais e em âmbito regional, bem como por meio de uma rede de relações bilaterais que estende-se a distintas regiões ${ }^{4}$.

No entanto, esses aspectos ressaltados no discurso diplomático são insuficientes para uma adequada compreensão do universalismo como dimensão característica da política externa brasileira e como condicionante da construção de parcerias internacionais do país. Isso porque sugerem ser o mesmo um subproduto, 
uma decorrência quase natural ou inevitável das características do país, seu território e população, de suas potencialidades e da aspiração de exercer papel ativo na cena internacional. Ao lado desses fatores, o universalismo deve também ser entendido como resultante do entrelaçamento de injunções domésticas e externas, os quais, por sua vez, condicionam os objetivos e estratégias de desenvolvimento, e, por conseqüência, as prioridades de política externa, o leque de opções de relacionamento, e, por fim, o estabelecimento de parcerias internacionais.

Portanto, a universalidade não é uma característica estática, nem em seu conteúdo nem em sua consecução histórica. No caso brasileiro, a afirmação do sentido universalista se deu, de forma gradual, a partir dos anos trinta, concomitantemente e em sintonia com a consagração do desenvolvimento como principal vetor da política externa ${ }^{5}$. A definição desse vetor requer, desde então, responsividade da política externa às circunstâncias e transformações do cenário internacional e, ao mesmo tempo, capacidade de adequação aos distintos matizes assumidos pelo nacionalismo ${ }^{6}$ internamente até o final dos anos oitenta, às inflexões da própria política externa, notadamente àquelas ocorridas a partir de final da década de cinqüenta ${ }^{7}$, e à prevalência do liberalismo econômico na condução da política interna e da política externa a partir dos anos noventa. Tais exigências somavam-se, em seus respectivos tempos, a necessidades a serem atendidas no plano internacional, e que, por sua vez, traduziram-se em um sentido de seletividade na política externa, com o qual se definiram e estruturaram as diferentes parcerias estratégicas do país.

Assim, a gradual formação de uma rede de parcerias estratégicas pelo Brasil vem atendendo a visões pragmáticas, partilhadas pelas elites governamentais (incluindo-se naturalmente o estamento diplomático) e pelos principais agentes econômicos, sobre oportunidades de realização de seus interesses e de resposta às necessidades colocadas pelo modelo de desenvolvimento, tomando em conta os limitados recursos de que dispõe o país para fazê-lo de modo adequado ${ }^{8}$. Portanto, o constante exercício do pragmatismo não implicou, em nenhum sentido, o sacrifício do substrato valorativo e dos princípios orientadores da política externa brasileira. Ao contrário, o pragmatismo, associado ao universalismo, é percebido como elemento tradicional da política externa e que, ao lado de valores e princípios por ela consagrados, lhe confere, enquanto política de Estado, alto grau de previsibilidade e uma sólida base de continuidade ${ }^{9}$.

A construção de parcerias estratégicas pelo Brasil associa-se, segundo Lessa, ao processo de escolha de parceiros preferenciais, no contexto do que ele denomina "universalismo seletivo"10. Em suas palavras, "a construção de parcerias estratégicas é fruto da compatibilização da vocação histórica do Brasil para a universalidade com a necessidade de aproximações seletivas, o que abre a possibilidade para movimentos de adaptação aos nichos de oportunidade e aos constrangimentos internacionais que se apresentam conjunturalmente" ${ }^{11}$. Por essa 
razão, universalismo, pragmatismo e o estabelecimento de parcerias estratégicas orientadas por um sentido de flexibilidade e não-excludência vêm representando, ao longo dos anos, importantes elementos operativos que conferem funcionalidade e adaptabilidade à política externa brasileira frente às mutantes condições do cenário internacional ${ }^{12}$, em suas expressões global, multilateral, regional e sub-regional. Sua construção supõe, ademais, um complexo (e nem sempre satisfatoriamente alcançado) ajuste de interesses, prioridades e compromissos definidos em distintos eixos e em circunstâncias igualmente diferenciadas.

Em razão do desafio que, em termos da implementação da política externa, essa sorte de ajuste representa, é importante considerar ser natural que inconsistências, incompatibilidades entre compromissos e objetivos assumidos no marco de determinado eixo, suscitem constrangimentos ou mesmo obstaculizem avanços em outros. Como nos faz recordar a historiadora Barbra Tuchman, não é exatamente uma anomalia histórica o fato de os Estados perseguirem objetivos não inteiramente compatíveis entre si, ou mesmo incongruentes com seus próprios interesses a médio e longo prazos ${ }^{13}$. O Brasil, em razão do próprio sentido universalista e pragmático de sua política externa e da diversidade de opções de parcerias estratégicas que procura explorar dentro de um critério de não excludência, tem sido suscetível a esse tipo de dificuldade ao longo dos anos, o que permite assumir, como hipótese, que o exercício de sua opção universalista realizada, dentre outros meios, por diferentes alianças estratégicas, afeta, de forma nem sempre positiva, a evolução do Mercosul, principal espaço e plataforma do protagonismo que o país procura exercer no plano externo. Faz-se, então, necessário caracterizar e contextualizar historicamente as iniciativas brasileiras voltadas para a construção de parcerias, para melhor compreendê-las em sua natureza, funcionalidade e em suas implicações para o Mercosul. Com esse propósito, nos parágrafos seguintes, relacionaremos tais parcerias às prioridades de política externa e aos modelos de desenvolvimento que as orientaram em diferentes momentos, para, posteriormente, analisar sua construção e suas implicações para o Mercosul no presente.

\section{Prioridades de política exterior e a construção de parcerias estratégicas: uma perspectiva histórica}

Como visto antes, a eleição do desenvolvimento como principal vetor de orientação da política externa brasileira ocorreu nos anos trinta, com a chegada de Getúlio Vargas ao poder, em um contexto internacional marcado pelas seqüelas da depressão econômica, traduzidas em acentuado protecionismo comercial, indisponibilidade de recursos externos para investimento e, no plano político, pela ascensão do totalitarismo. Com a contraposição do totalitarismo em suas expressões nazista e fascista às democracias ocidentais, estabeleceu-se uma clivagem política da qual o Governo Vargas buscou tirar proveito, assumindo posicionamentos 
ambíguos, com o que esperava poder extrair benefícios para a promoção do desenvolvimento econômico, sob uma visão nacionalista, que tenderia a reforçarse nos anos seguintes. No entanto, e por força da lógica do próprio modelo de desenvolvimento vigente, como também dos desdobramentos da crise internacional que culminaram com a Segunda Guerra Mundial, o Brasil terminou por estreitar laços com os Estados Unidos, dando início a um padrão de relacionamento com aquele país definido pela alternância de períodos de aproximação e de relativo distanciamento, estando estes últimos relacionados a esforços, pelo Brasil, de afirmação de autonomia externa. Esse padrão de relacionamento desenvolveu-se, de forma geral, sob um marco cooperativo que caracterizaria, a partir de então, as relações entre ambos países, sem chegar, contudo, a configurar um relacionamento privilegiado, embora expectativas nesse sentido tenham sido nutridas, a partir do Governo Dutra, por diferentes governos, em circunstâncias específicas. A realidade, porém, viria a demonstrar que, por razões afetas a ambos países, qualquer forma de relacionamento especial com os Estados Unidos não seria factível. A própria cooperação no campo militar, estabelecida por meio de acordo celebrado em 1953 (e que fora objeto de polêmica no Brasil), terminaria por desenvolver-se sem sincronismo direto com a cooperação econômica, que fora fortemente condicionada pelo nacionalismo brasileiro, por um lado, e, por outro, pela prioridade conferida pelos Estados Unidos ao enfrentamento ideológico ao comunismo no Continente. Assim, ao não estabelecer-se um alinhamento automático com os Estados Unidos durante a segunda metade dos anos cinqüenta e nos primeiros anos da década de sessenta, a política externa brasileira logrou ser conduzida com base na flexibilidade e no pluralismo, permitindo ao Brasil exercer relativa autonomia no aproveitamento de oportunidades nos planos político e econômico, sem descaracterizar, contudo, seu comprometimento ideológico com o Ocidente no contexto da Guerra Fria ${ }^{14}$, coincidindo com "um dos raros períodos (na política externa brasileira) no qual o eixo da política latino-americana aparece em relativa sintonia com o da relação norte-americana $(\ldots)^{\prime 15}$.

Esse quadro viria a alterar-se em favor de um mais intenso alinhamento do Brasil aos Estados Unidos entre 1964 e 1967, sendo, contudo, superado logo em seguida, embora em um contexto externo já marcado pela crescente multipolaridade no plano econômico e com a economia brasileira crescendo a taxas elevadas e com uma base industrial já consolidada. Isso trouxe dois desdobramentos importantes em termos de formação de parcerias externas: em primeiro lugar, fortaleceram-se as condições para o exercício do pragmatismo na política externa, estando esta voltada para fins definidos em uma perspectiva nacionalista ${ }^{16}$; em segundo, consagrou-se o universalismo seletivo com a consecução de uma estratégia de diversificação de parcerias com as quais o Brasil almejaria extrair benefícios para seu projeto de desenvolvimento e, concomitantemente, exercer maior influência 
externa e elevar sua capacidade de barganha nos foros multilaterais e em eixos bilaterais.

Autonomia, pragmatismo e diversificação das parcerias: Alemanha e Japão

Como parte desse esforço de diversificação de parcerias, surgiram, no Governo Geisel (1974/79), as primeiras iniciativas visando ao estabelecimento de alianças estratégicas com países industrializados e que implicaram o acirramento de divergências com os Estados Unidos e com a Argentina ${ }^{17}$. Dois países, Alemanha e Japão, representavam, para o Brasil, opções de relacionamento que lhe permitiriam, por um lado, aprofundar suas relações com os países industrializados ao mesmo tempo em que afirmava seus esforços de "autonomia periférica"18 frente aos Estados Unidos; por outro, permitir-lhe-iam aceder a recursos indispensáveis à construção da potência, objetivo incansavelmente perseguido pelos governos militares, e, por fim, responder a necessidades financeiras e aos entraves estruturais postos em questão pela crise do petróleo e pela recessão econômica generalizada que a esta se seguiu.

Cumpre notar que essas parcerias foram construídas a partir de vínculos políticos, econômicos e sócio-culturais pré-existentes ${ }^{19}$, e que conferiam bases para o adensamento das relações bilaterais por meio de arrojadas iniciativas de cooperação. Com a Alemanha, o Brasil mantivera intenso relacionamento econômico desde os anos cinqüenta e que aprofundara-se ainda mais ao final da década de sessenta, quando aquele país tornou-se o maior exportador mundial líquido de capitais ${ }^{20}$. A intensificação das relações econômicas, a partir das décadas de setenta e oitenta, levou a Alemanha à condição de segundo principal investidor estrangeiro no Brasil, respondendo então por cerca de $13 \%$ dos investimentos diretos realizados no país ${ }^{21}$, com peso muito importante no desenvolvimento industrial brasileiro. No tocante ao comércio, a Alemanha passou a ser o terceiro parceiro comercial do Brasil e o primeiro no âmbito da Europa Ocidental, passando a ser o Brasil, por sua vez, o mais importante parceiro alemão fora do âmbito da OCDE. Nas áreas de cooperação financeira, técnica e científica tecnológica há igualmente um intenso relacionamento englobando áreas como proteção ambiental, formação de recursos humanos, energia, biotecnologia e o setor aeroespacial, dentre outros.

No entanto, foi o Acordo sobre Cooperação no Campo dos Usos Pacíficos da Energia Nuclear firmado em 1975, e considerado então fundamental para o pretendido domínio, pelo Brasil, do ciclo do combustível nuclear, que sinalizou a disposição de ambos países de construir sólida parceria para além dos planos comercial e financeiro. Assim, apesar dos inúmeros percalços na implementação do Acordo e dos resultados muito aquém do esperado, o mesmo teve importante significado político em nível bilateral, dado ter sido a Alemanha o único país então 
disposto à cooperação nuclear com o Brasil nos termos por este desejados ${ }^{22}$. As dificuldades econômicas do Brasil, com o aprofundamento da crise financeira na segunda metade dos anos setenta, acentuaram as contradições do modelo de substituição de importações; posteriormente, a superação da bipolaridade e a reunificação alemã, e os compromissos assumidos pela Alemanha no âmbito da integração européia praticamente inviabilizaram a continuidade da parceria nos termos originalmente concebidos, e gradualmente minaram as condições que a haviam sustentado.

As relações com o Japão, por sua vez, ganharam intensidade igualmente a partir da segunda metade dos anos 50, com um primeiro ciclo de investimentos voltados para o fornecimento regular de matérias-primas e a expansão das exportações de manufaturas japonesas. A esse ciclo, seguiu-se outro no qual foram expandidas e diversificadas as exportações japonesas para o Brasil. Nesse sentido, a dimensão estratégica da parceria com o Brasil associava-se, pelo lado japonês, ao interesse em assegurar o suprimento de matérias-primas e alimentos, reduzindo, ao mesmo tempo, sua dependência nesses campos em relação aos Estados Unidos; pelo lado brasileiro, associava-se ao acesso a recursos e tecnologias para o desenvolvimento de grandes projetos industriais (siderurgia notadamente) e à diversificação de mercados de exportação. Assim, do ponto de vista dos investimentos, o Japão passou a representar o quarto principal investidor estrangeiro no Brasil, respondendo por cerca de $6 \%$ dos investimentos diretos ${ }^{23}$. As relações comerciais também incrementaram-se à medida em que também maturaram os investimentos japoneses e em que a economia brasileira expandia-se. Porém, e à despeito da industrialização brasileira, consolidou-se um padrão tradicional de comércio entre ambos países, com o Brasil importando bens industrializados e exportando produtos primários ${ }^{24}$.

A parceria com o Japão, portanto, foi construída sobre uma base de complementaridade, com o Brasil fornecendo matérias-primas em troca de investimentos e produtos industrializados. Apesar desse perfil que supostamente induziria a noção de serem as relações econômicas de maior interesse relativo para o Brasil, o relacionamento nipo-brasileiro foi muito mais marcado pelos interesses e iniciativas japonesas ${ }^{25}$, como o atestam sua presença no setor siderúrgico e o desenvolvimento de projetos de cultivo de soja no Cerrado brasileiro, que retiraram o Japão da dependência dos Estados Unidos em relação ao suprimento desses produtos e inviabilizaram o controle que aquele país exercia sobre seus preços no mercado internacional. Assim como ocorrido com a Alemanha, a parceria com o Japão enfrentou dificuldades crescentes com o aprofundamento da crise econômica brasileira e com a emergência dos países do Sudeste Asiático como opções mais funcionais aos interesses japoneses então.

Alguns aspectos presentes em ambas parcerias devem ser ressaltados para a melhor compreensão de sua natureza e características. Elas adquiriram 
funcionalidade para o Brasil, em primeiro lugar, ao permitir a consecução da defesa de interesses de comércio exterior e a garantia de suprimento adequado de insumos, recursos, produtos e tecnologias essenciais ao desenvolvimento econômico, cuja promoção representou o objetivo fundamental da política externa tal como definido pelo pragmatismo responsável que a orientou até meados dos anos oitenta ${ }^{26} ; \mathrm{em}$ segundo lugar, permitiram ao país maior margem de autonomia frente aos Estados Unidos, ao diversificar as opções de acesso a mercados e a fontes de investimentos e tecnologias em um contexto em que acentuavam-se suas vulnerabilidades frente à crise econômica que instaurava-se internacionalmente a partir do primeiro choque do petróleo; em terceiro lugar, atenderam ao propósito de diversificar as relações econômicas com os países industrializados; e, por fim, contribuíram para projetar internacionalmente o país a partir de um perfil calcado em interesses nacionalmente definidos.

No entanto, cabe salientar também que a funcionalidade das parcerias estabelece-se não somente em razão dos objetivos e prioridades da política externa, mas associa-se também a aspectos conjunturais que realçam seu valor e favorecem sua implementação ${ }^{27}$. Assim, as parcerias do Brasil com Alemanha e Japão puderam beneficiar-se de um conjunto de fatores contextuais que lhes conferia operacionalidade: foram estabelecidas na esteira de longo período de crescimento e de afirmação da crescente multipolaridade econômica que, ao lado de outros fatores, lhes permitia, respectivamente, afirmar interesses de maior autonomia relativa frente aos Estados Unidos concomitantemente à busca de um reposicionamento no jogo de poder internacional. Em outras palavras, as parcerias do Brasil com a Alemanha e o Japão, além do sentido de complementariedade que as orientava, foram também condicionadas pelas relações de cada país considerado com os Estados Unidos e não estavam desvinculadas, pois, das transformações que afetavam o próprio sistema internacional e as bases da hegemonia norte-americana. Eram, antes, respostas a tais mudanças e formas parciais pelas quais procuravase avançar interesses, reduzir vulnerabilidades e auferir ganhos.

Portanto, ao exaurirem-se as condições que favoreceram e impulsionaram a construção dessas parcerias, elas perdem gradativamente sua operacionalidade até serem reformuladas ou, mesmo, temporariamente, suplantadas.

Eram, ademais, parcerias assimétricas quanto às dimensões econômicas dos países envolvidos, quanto a seu peso específico no cenário internacional e quanto aos distintos significados e alcance político para cada parte: para o Brasil, elas possuíam caráter instrumental de alavancagem do desenvolvimento, de redução de vulnerabilidades e de elevação de seu status de poder e de questionamento da legitimidade da própria ordem econômica internacional; para Alemanha e Japão, o relacionamento com o Brasil contribuía parcialmente para consolidar seu poder econômico, sem, contudo, representar qualquer forma de questionamento ao ordenamento econômico internacional vigente. Daí porque o potencial de fricção 
que delas decorria ter sido maior para o Brasil que para suas contrapartes, notadamente em relação aos Estados Unidos.

Porém, no caso brasileiro, além dos Estados Unidos, esse potencial de fricção também estendeu-se às relações com a Argentina, exacerbando momentaneamente desconfianças quanto ao que se interpretava como pretensão hegemônica por parte do Brasil e fomentando percepções confusas sobre o protagonismo que o país buscava exercer no plano regional. Esse protagonismo retratava, de forma coerente, a prioridade conferida, a partir do Governo Geisel, à América Latina enquanto espaço geográfico a partir do qual se deveria desenvolver o esforço de auto-afirmação brasileira e onde o país procuraria exercer papel de "catalisador" do diálogo ${ }^{28}$.

No entanto, a prioridade então assignada à América Latina e, secundariamente, a outras regiões em desenvolvimento, dentre as quais a África, não esteve apoiada, em sua execução, em nenhum eixo bilateral em particular, que denotasse um sentido de construção de parceria estratégica. E isso porque, para o Brasil, as relações com a região, e mais particularmente com os países do Cone Sul, refletiam uma preocupação justificada com a manutenção de equilíbrio e da estabilidade $^{29}$; além disso, a importância relativa da América Latina para o Brasil fixava-se inicialmente muito mais no sentido político que econômico: os fluxos comerciais estavam direcionados, em sua maior parte, para os países industrializados enquanto principais fornecedores de capitais e insumos para o desenvolvimento econômico do país; ademais, frente às vulnerabilidades externas que se acentuaram ao longo dos anos setenta e oitenta e à própria natureza dos regimes políticos então vigentes, tornou-se muito difícil para o Brasil e para os demais países da região estabelecerem entre si, naquele contexto, qualquer forma de vínculo associativo privilegiado, mesmo que o fosse para fazer frente à crise econômica que atravessavam $^{30}$.

Portanto, sob este ponto de vista, pode-se afirmar que as prioridades da política externa definidas em termos de espaços geográficos não correspondiam plenamente, no que se refere à construção de alianças estratégicas, às prioridades temáticas, estas de fundo essencialmente econômico, com exceção talvez ao que respeita ao suprimento de petróleo que levou a uma maior aproximação do Brasil com a Venezuela e, em menor medida, com o Equador. E foi precisamente em torno das questões de acentuado conteúdo econômico, embora destinadas a finalidades também políticas, que o país procurou estruturar suas principais parcerias internacionais naquele contexto, o que tornava natural terem recaído precisamente em dois países industrializados as opções do Brasil para tal fim. Disso, contudo, não se deve inferir ter a opção pelo estabelecimento de parcerias com países industrializados induzido o Brasil a distanciar-se de seus vizinhos; ao contrário, ao referido acirramento de conflitos e desconfianças que provocou junto à Argentina, 
e, de forma menos intensa, a outros países da região, seguiram-se esforços de aproximação iniciados ainda durante o Governo Geisel, intensificados no Governo Figueiredo e que conduziram à celebração do Acordo de Itaipú-Corpus com a Argentina, abrindo caminho para a superação definitiva do padrão conflitivo que marcara historicamente o relacionamento entre ambos e inaugurando uma nova fase de integração; conduziram ainda ao Tratado de Cooperação Amazônica de 1978, aproximando o Brasil dos países andinos, em uma outra frente, marcando a disposição brasileira de dissipar, junto aos seus vizinhos, as percepções desfavoráveis baseadas na inércia e na desconfiança.

O que se pode notar, enfim, é que, durante a prevalência do "pragmatismo responsável" como expressão de sua política externa, as parcerias construídas pelo Brasil, se, por um lado, não implicaram o afastamento de seu entorno regional, por outro, não representaram também fator de estímulo direto ou indireto, em seus desdobramentos, para uma maior aproximação brasileira aos seus vizinhos. Essa aproximação deveu-se mais à afirmação do próprio interesse brasileiro em exercer papel protagônico e à crescente convergência que passaria a marcar o próprio relacionamento com os países da região que a qualquer vínculo indeclinável entre a realização de seus interesses por meio de parcerias com países industrializados e o atendimento de condições necessárias para a maior cooperação no plano regional. Ao mesmo tempo, a aproximação iniciada, no plano regional, não esteve amparada na busca de nenhum relacionamento especial, em nível bilateral, que atuasse como catalisador para a consecução dos interesses de política externa na região. Assim, até a metade dos anos oitenta, o estabelecimento de parcerias estratégicas foi elemento muito mais operacional de prioridades definidas em relação ao mundo industrializado que daquelas definidas em relação à América Latina e outras regiões do mundo em desenvolvimento.

Esse quadro, no entanto, viria a alterar-se a partir do Governo Sarney (1985/90), quando convergiram importantes mudanças no cenário internacional e regional que inscreveram, de forma definitiva, a América Latina, e particularmente o Cone Sul, como espaço essencial de projeção de interesses brasileiros e no qual o país construiria sua mais importante e abrangente parceria estratégica.

\section{O ocaso do nacional-desenvolvimentismo e a redefinição de parcerias: a aproximação com a Argentina}

O comprometimento com a plena restauração e consolidação da democracia condicionou a política externa do Governo Sarney (1985/1990) e refletiu-se, sobretudo, na forma com que suas prioridades passaram a ser operacionalizadas ${ }^{31}$. O Governo Sarney confrontou o desafio de adaptar a política externa do país às novas condições do cenário internacional e do próprio país, procurando superar 
desconfianças geradas regional e globalmente pela orientação autárquica e baseada em uma leitura hobbesiana com a qual os governos militares conduziram a política externa. Procurou ainda restabelecer a interlocução com os países industrializados em diversos planos, inclusive nos foros multilaterais, que havia igualmente sido afetada pelo sentido muitas vezes dissonante conferido à condução externa do país em períodos anteriores.

Manteve-se, assim, a projeção universalista da política exterior, mas, dentro dela, foi fortalecida e ampliada a prioridade às relações com a América Latina, relações estas que, apesar e em razão mesmo da crise econômica que assolava a região, encontravam, finalmente, um sentido de funcionalidade no plano econômico ${ }^{32}$. Também tornara-se imperioso reorientar vários projetos de desenvolvimento concebidos no regime militar, seja pela absoluta carência de recursos, dramatizada pelos efeitos da crise econômica, seja pela falta de legitimidade que, em um marco de redemocratização, os tornava além de econômica, politicamente inexeqüíveis. Tornara-se evidente o esgotamento do modelo de desenvolvimento que o país havia perseguido por décadas, e ao qual a política exterior e as alianças até então entabuladas haviam servido, sem que o Governo então lograsse imprimir nova estratégia para orientar o desenvolvimento econômico e a inserção externa do país.

No entanto, a retificação de muitas das linhas de política externa então conduzidas não implicou o abandono das prioridades já consolidadas, sobretudo daquelas definidas em termos de espaços geográficos. Foi, sobretudo, a forma de dar conteúdo e concretude a tais prioridades que modificou-se sensivelmente, o que foi evidenciado, de forma particular, no plano das relações com a América Latina $^{33}$. Até então, como dito acima, estas estavam definidas muito mais por sua importância política que por sua densidade econômica, diferentemente do que ocorria com as parcerias buscadas no Primeiro Mundo. A partir de então, essa importância política passaria a encontrar correspondência também no campo econômico, tanto por meio de iniciativas bilaterais como pela retomada da cooperação multilateral.

No início dos anos oitenta, os países latino-americanos procuraram, com pouco êxito, revigorar os esforços de integração econômica regional, como estratégia de resposta parcial à crise econômica; dadas as dificuldades com o regionalismo econômico, em sua vertente multilateral, restava a valorização de eixos bilaterais como única opção viável de dar operacionalidade política e econômica à prioridade conferida à América Latina no âmbito da política externa brasileira. E, como sabido, o advento de governos civis no Brasil e na Argentina veio a gerar uma base de convergência política com a qual buscariam, por meio do aprofundamento da interdependência econômica e uma inédita cooperação no campo nuclear, retirar definitivamente dos militares os argumentos confrontacionistas do passado e buscar o afiançamento recíproco da democracia, reduzindo possibilidades de retrocesso político. 
Assim, a parceria com a Argentina, desenhada gradualmente a partir de 1985, estava orientada por um claro sentido político, relacionado à consolidação democrática, e tendo, como elemento instrumental, o alargamento da interdependência econômica que se procurou construir mediante ações de cooperação em um amplo espectro de setores. São muito bem conhecidas as motivações e a forma com que transcorreram as relações entre Brasil e Argentina a partir de então, não sendo nosso propósito aqui recapitulá-las. No entanto, alguns aspectos devem ser explicitados no que se refere à parceria com a Argentina em relação às demais entabuladas pelo Brasil e que a diferencia substantivamente destas.

Em primeiro lugar, diferentemente do que ocorrera em relação à Alemanha e ao Japão, e pela primeira vez, o Brasil constrói uma parceria simétrica e calcada em uma convergência de interesses e de propósitos políticos definidos em um marco de restauração da democracia. A maior simetria e o conteúdo abrangente proposto para essa parceria, refletidos nos protocolos bilaterais assinados em 1986, e posteriormente no Tratado de Integração, Cooperação e Desenvolvimento, de 1988, demandavam mecanismos mais complexos de articulação de interesses, e, consequentemente, de legitimação; refletiam também os objetivo pretendidos: a longo prazo, a promoção de desenvolvimento conjunto no quadro de uma integração a ser construída a partir do enlace de setores produtivos e de iniciativas em campos fundamentais como energia, transporte, telecomunicações, dentre outros. Ao mesmo tempo, e de forma imediata, almejava-se atuar cooperativamente, no sentido do afiançamento e reforço mútuo frente a problemas comuns tanto no campo político como no econômico, onde alta inflação e o endividamento externo constituíam um desafio comum.

Embora as condições para a construção da parceria com a Argentina estivessem sendo gradativamente dadas desde os dois últimos governos militares brasileiros, e apesar do decisivo exercício de uma intensa diplomacia presidencial e do ainda escasso envolvimento de outras instâncias sócio-políticas no debate e na condução das relações com a Argentina naquele momento, as iniciativas de integração passaram a representar um campo privilegiado de exercício de diálogo entre o Executivo e o Legislativo e outros segmentos sociais, notadamente o empresariado e os trabalhadores, o que se acentuaria a partir da criação do Mercosul em 1991.

Outro aspecto a merecer destaque é o fato de, também pela primeira vez, ter se construído uma parceria envolvendo temas sensíveis, como cooperação no campo nuclear, e, igualmente, no campo da segurança, sem suscitar conflitos com os Estados Unidos. E isso se deveu basicamente aos seguintes fatores: em primeiro lugar, a própria aproximação entre Brasil e Argentina teve, como pano de fundo, um sentimento de relativa frustração, de parte de cada país, quanto aos seus intentos, 
levados a efeito em diferentes momentos, de estabelecer um relacionamento privilegiado com os Estados Unidos ${ }^{34}$; desse modo, a aproximação Brasil-Argentina não destinava-se a representar oposição ou confrontação aos Estados Unidos. Em segundo lugar, por resultar em sensível melhora dos níveis de estabilidade política no Cone Sul e por reforçar o sentido da consolidação da democracia na região, essa aproximação permitiria aos Estados Unidos concentrar atenção em outras áreas e temas em que percebiam maior comprometimento de seus interesses; finalmente, não eram percebidas, até então, possibilidades de que a cooperação que se arquitetava pudesse implicar maiores embaraços aos interesses econômicos dos Estados Unidos. Apesar da emergência de blocos comerciais, o esforço de liberalização comercial, naquele momento, estava sendo canalizado para as negociações no âmbito do Acordo Geral de Tarifas e Comércio (GATT), não se prestando muita credibilidade aos esforços de integração regional na América Latina.

Importante notar também que a construção da parceria estratégica com a Argentina iniciou-se em um contexto em que as variáveis tanto de índole interna quanto externa que haviam contribuído para forjar e dar objetividade às parcerias com os países industrializados haviam se modificado profundamente, tornando-as, em grande medida, inoperantes quanto aos seus objetivos maiores. Para isso, muito contribuíram as condições internas da economia brasileira então, e, ainda mais, as posições assumidas pelo Brasil quanto à dívida externa, particularmente a moratória decretada em 1987 e que indispôs fortemente o país com seus principais credores que também eram suas contrapartes nas principais parcerias estratégicas.

Assim, no Governo Sarney, deram-se as condições para que o Brasil estabelecesse sua principal e mais abrangente parceria estratégica e que serviria de plataforma para redefinir suas relações no plano regional e, no momento seguinte, instrumentalizar sua inserção externa já em um contexto internacional profundamente modificado pela superação da confrontação Leste-Oeste, pela emergência de blocos econômicos, pela gradual afirmação do liberalismo econômico e da democracia como valores fundacionais da ordem internacional emergente. Ao mesmo tempo, esse esforço esteve condicionado pelas restrições de ordem econômica que, interna e externamente, enfrentavam ambos países, mas que, simultaneamente, representaram estímulo para uma maior aproximação política. No entanto, embora aproveitando plenamente as possibilidades que emanavam do novo quadro político interno em favor da integração bilateral, o Governo Sarney, assim como o Alfonsín, não logrou definir um novo paradigma de desenvolvimento capaz de orientar o sentido de sua política externa. Assim, esgotara-se o antigo paradigma ao qual a política externa servira, e, por conseqüência, perderam funcionalidade as alianças estratégicas então forjadas, sem que se introduzisse, naquele momento, outro paradigma, o que somente viria a ocorrer a partir de 1990, com a chegada de Collor de Melo ao poder. 


\section{A política externa em tempos de abertura econômica e globalização: a lógica das novas parcerias}

A curta passagem pelo poder de Fernando Collor de Mello, primeiro presidente eleito diretamente em quase três décadas, impactou de forma significativa na política externa brasileira. Tratava-se, já nos albores do pós-Guerra Fria, de implementar reformas econômicas de corte liberal e que tinham a abertura, a desregulamentação e a privatização como medidas indeclináveis para a retomada do desenvolvimento e para tornar a economia brasileira competitiva internacionalmente. Ao mesmo tempo, procurar-se-ia restaurar a credibilidade externa do país, que seguia ainda abalada por um legado de projetos herdados do regime militar e não totalmente suplantados pelo Governo Sarney, por medidas como a moratória da dívida externa e, também, pelos fracassos no controle da inflação e no combate à corrupção internamente.

De forma imediata, a política externa passaria a servir a um duplo propósito: instrumentalizar, no âmbito externo, o processo de reforma e de abertura econômica e restaurar a credibilidade externa do país junto aos seus interlocutores, principalmente, no âmbito dos países desenvolvidos. Procurava-se romper com a identificação do país com o contexto do subdesenvolvimento e imprimir um perfil renovado e convergente com as teses e postulações de modernidade dos países desenvolvidos. Segundo Hirst, três metas foram então estabelecidas para atender a esses objetivos: atualizar a agenda internacional do país, construir uma agenda positiva com os Estados Unidos e descaracterizar o perfil terceiro-mundista do Brasi $^{35}$. Em uma perspectiva mediata, a política externa estaria voltada para o aumento da competitividade internacional do país mediante a abertura econômica e a busca de condições favoráveis de acesso a mercados, créditos e tecnologias ${ }^{36}$. Frente a esses objetivos, reafirmava-se a funcionalidade e o sentido predominantemente econômico a ser imprimido às parcerias internacionais ${ }^{37}$.

Cumpre notar, pois, um elemento recorrente: a preocupação em alterar o perfil do relacionamento com os países industrializados e, em particular, com os Estados Unidos. Isso, contudo, sem desqualificar o sentido universalista da política externa e, mais particularmente, sem comprometer os avanços obtidos nas relações com os países do Cone Sul. Tais esforços, matizados por posturas por vezes voluntaristas e por um conjunto de medidas unilaterais com as quais se procurava ganhar a confiança dos principais interlocutores externos, não resultaram no estabelecimento de parcerias, nos moldes até então empreendidos. A rigor, seguiase rejeitando a possibilidade de alinhamento ou relação privilegiada com os Estados Unidos, mesmo reconhecendo sua condição inconteste de única superpotência global.

A leitura que orientaria, a partir de então, a formulação da política externa assumia que o sistema internacional passava a caracterizar-se, do ponto de vista 
da distribuição do poder, por "polaridades indefinidas", pela persistência e alargamento de assimetrias, e pela coexistência de forças de integração e de dispersão ${ }^{38}$. Em um tal contexto, assumia-se que a estratégia visando projetar os interesses brasileiros e redefinir o perfil externo do país deveria pautar-se na ação simultânea e com sentido de reforço mútuo, tanto no plano das vinculações bilaterais, no âmbito regional e nos foros multilaterais, objetivando o aproveitamento de possibilidades que revertessem em favor da modernização da economia e da restauração da credibilidade externa do país. Essa mesma lógica passaria a orientar o processo de integração com a Argentina, o que implicou o abandono da estratégia integracionista perseguida anteriormente, baseada na aproximação setorial enquanto alavanca de maior interdependência, em favor da liberalização progressiva, automática e linear do comércio, e com a qual, além do avanço em termos da integração econômica, se procurava sinalizar aos países industrializados e aos investidores internacionais a disposição quanto à abertura econômica do país em sentido geral.

A integração, e, consequentemente, a parceria com a Argentina, ganhou então novo sentido de funcionalidade imediata: passou a representar espaço e oportunidade de aprendizado e adaptação dos setores privados para a abertura econômica e para a exposição à concorrência ${ }^{39}$, segundo a lógica do mercado, representando também uma resposta adaptativa à formação de blocos econômicos. O Mercosul constituiria, segundo essa lógica, o espaço no qual as agendas econômicas domésticas se vinculariam às tendências da economia mundial e a partir do qual os países membros negociariam sua inserção internacional, sendo esse então o sentido estratégico a ele outorgado.

Desde então, e de forma crescente, as relações externas do Brasil, no campo econômico, passaram a tomar como referência os desenvolvimentos no âmbito do Mercosul, o que se torna mais nítido particularmente a partir da assinatura do Protocolo de Ouro Preto que culminou o período de transição no qual se procedera a liberalização do comércio entre os países membros e que definiu o arranjo institucional do Mercosul, dotando-o de personalidade jurídica no plano internacional. Significa dizer que, através do Mercosul, e das vinculações externas que este passou a construir, desdobrando em outras vertentes, é que se vem definindo, parcialmente, as próprias vinculações econômicas externas do Brasil e sendo forjadas novas parcerias internacionais.

O afastamento de Collor de Melo, e a ascensão de seu Vice, Itamar Franco, não implicou rupturas na política externa. Foram reafirmadas as linhas gerais introduzidas em 1990 e procedidas correções que visaram corrigir excessos da postura voluntarista com a qual Collor procurou descaracterizar o perfil terceiromundista do Brasil, reenquadrando, no discurso diplomático, sua condição de país em desenvolvimento identificado com as causas e necessidades do Sul, mas igualmente buscando restabelecer e renovar seus vínculos com o mundo 
industrializado ${ }^{40}$. Se, em linhas gerais, a política externa refletia continuidade, houve, contudo, uma mudança importante quanto ao protagonismo brasileiro em âmbito regional: o Governo Itamar Franco, apesar de uma breve fase de indecisão inicial, reafirmou e acentuou a prioridade à consolidação do Mercosul e, ao mesmo tempo, procurou articular novas iniciativas que ampliassem à toda a América do Sul o alcance da integração iniciada no Cone $\mathrm{Sul}^{41}$. Apesar de não haverem prosperado, essas propostas tiveram o mérito de inscrever a perspectiva de integração regional como elemento no cálculo estratégico dos países do Mercosul frente às propostas de integração de alcance continental, como a formulada pelos Estados Unidos em dezembro de 1994.

Outro aspecto a ser destacado na política externa de Itamar Franco, por sua relação direta com o tema ora considerado, foi a revalorização da dimensão africana $^{42}$, desta vez incorporando as relações com a África do Sul como principal vetor de reaproximação com os países daquele continente e para a retomada de propostas políticas, como a criação da Zona de Cooperação do Atlântico Sul. A partir das transformações políticas que conduziram ao fim do regime de apartheid, e com o reconhecimento do governo e dos empresários brasileiros da importância da África do Sul em termos políticos e econômicos e de sua influência e potencialidades em termos regionais, colocaram-se as condições para construir uma relação que, claramente, reveste-se de importância estratégica para o país e que tem implicações potenciais e possibilidades positivas para o Mercosul, como se explicitará adiante.

Enfim, o Governo Itamar Franco empreendeu esforços no sentido de ampliar os vínculos do país no próprio continente sul-americano e na África. Fê-lo, no entanto, a partir de iniciativas de caráter multilateral: exemplos foram a Área de Livre-Comércio da América do Sul (ALCSA), a Iniciativa Amazônica e a Comunidade dos Países de Língua Portuguesa. Desse modo, em termos de construção de parcerias com países em desenvolvimento, os avanços restringiramse à Argentina, com a consolidação da área de livre-comércio e da feição institucional do Mercosul, e à emergência da África do Sul como parceiro potencial.

No plano de parcerias com países industrializados, houve pouco ou nenhum progresso, o que se explica pela concentração de esforços em foros multilaterais ${ }^{43}$, por um lado, e pelo relativamente elevado grau de incerteza de parte dos próprios países industrializados e dos seus respectivos setores empresariais quanto às perspectivas econômicas do Brasil, mesmo diante do êxito das medidas de estabilização postas em marcha a partir de junho de 1994, já praticamente ao final da gestão Itamar Franco. Além disso, conjunturalmente, as atenções estavam, de forma geral, voltadas para os resultados da Rodada Uruguai e para seus desdobramentos no plano econômico, não tendo sido, portanto, um período oportuno para iniciativas bilaterais. 


\section{A política exterior a partir de 1994: a conjunção da democracia com a estabilidade econômica - velhas e novas parcerias e desdobramentos para o Mercosul}

Com a implantação das medidas de estabilização econômica em 1994, inicia-se, para o Brasil, uma fase em que estão presentes duas condições cruciais para o desenvolvimento do país e que impactará em sua política externa e, consequentemente, no exercício de construção de parcerias: estabilidade política em um marco democrático e crescimento com abertura econômica. Esse novo quadro interno, aliado às incertezas que continuaram marcando o cenário internacional, passou a exigir maior abertura à participação social e criatividade no campo da política externa, o que se tem realizado, mas sempre com a preocupação de não descaracterizar seus elementos de continuidade. Em face disso, o Brasil vem procurando adotar uma postura na qual procura ajustar os imperativos do novo modelo de desenvolvimento, calcado no liberalismo econômico, com a opção de preservar e exercer autonomia relativa na condução de sua política exterior, mesmo que, para tanto, sejam redefinidos substantivamente o sentido dessa autonomia e a forma de atuar para resguardá-la. Trata-se claramente de resposta que, em termos de condução da política exterior, reflete os próprios paradoxos do sistema internacional contemporâneo.

$\mathrm{O}$ esforço de equilibrar necessidades nacionais e as possibilidades e restrições colocadas por um contexto de crescente globalização passa a requerer formulações que racionalizem e permitam expressar, de modo coerente, a orientação da política externa, e que a legitimem internamente. Nas palavras do atual Chanceler, "É essencial ter presente, portanto, que a defesa de margens para escolhas próprias não se confunde mais, como ocorreu no passado, com a noção de auto-suficiência. Muito pelo contrário: em nossos dias, autonomia passa necessariamente pela integração com outros países, e não apenas no âmbito regional, mas também por parcerias internacionais cuidadosamente construídas e aprofundadas. Passa, ainda, diferentemente do que se poderia intuir, por um mundo governado não por menos e sim por mais regras internacionais; sobretudo por decisões e acordos que atendam às nossas necessidades e interesses" ${ }^{\prime 4}$.

Como se percebe, a construção de parcerias internacionais mantém, no presente, o mesmo sentido de funcionalidade que em períodos anteriores, dado que a política externa continua fundamentalmente voltada para a realização de interesses de desenvolvimento: "De modo geral, entretanto, parece correto dizer que, no caso do Brasil, (...) o objetivo principal é conseguir do intercâmbio externo elementos úteis à realização da meta prioritária do desenvolvimento, tanto em sua dimensões econômica e social, como também em áreas como direitos humanos, políticas públicas e meio ambiente. Em síntese, elementos que sirvam ao desenvolvimento na acepção mais abrangente do conceito. As parcerias externas são um 
complemento indispensável para os esforços de desenvolvimento, embora não tenha deixado de ser verdade que o fator determinante continuam a ser as boas políticas internas" ${ }^{45}$. O que se redefine, na verdade, é o modelo de desenvolvimento ao qual a política externa se põe a serviço. No caso brasileiro, no entanto, a mudança radical quanto ao estilo de desenvolvimento não refletiu-se de forma simétrica na política externa, que, como dito antes, comportará muito mais ajustes à orientação liberal, sem relegar, contudo, elementos que a definiram em períodos anteriores.

Ao mesmo tempo, a consolidação de um quadro de estabilidade econômica, a firme disposição do governo brasileiro de propiciar condições favoráveis aos investimentos externos, o avanço do processo de privatização e as crises que enfrentaram as economias mexicana e dos países do Sudeste Asiático representaram fatores favoráveis à ampliação de espaços para a concertação de interesses econômicos externamente, tanto a nível governamental como privado. Nesse contexto, a diplomacia foi incumbida de "apresentar o Brasil como país que está superando seus passivos e hoje se afirma pela estabilidade e robustez de sua economia, por sua democracia amadurecida, e por um comportamento de mainstream, isto é, sintonizado com a convergência internacional de posições em matéria de segurança, preservação ambiental, direitos humanos, e de combate ao crime organizado"46. Desse modo, tanto em razão das circunstâncias internas quanto da perspectiva externa, o reforço das parcerias internacionais é recontextualizado e retomado dentre as prioridades da política externa brasileira, agora não restringindo-se a países individualmente, como no passado, mas tendo por referência os principais blocos econômicos que passaram a compor o panorama da economia mundial.

Assim, a prioridade ao reforço de parcerias está voltada, segundo o discurso oficial, para Estados Unidos, Argentina, União Européia e Japão ${ }^{47}$. No entanto, é preciso qualificar cada caso com o propósito de avaliar em que medida se está tratando realmente de reforçar ou de construir parcerias, uma vez que, se consideradas em sua evolução até o presente, é inadequado atribuir às relações com os Estados Unidos e com a União Européia a conotação de parceria ou de aliança estratégica. Ao mesmo tempo, independentemente de prestar-lhes tal conotação ou não, reconhece-se que as mesmas trazem implicações importantes para o Mercosul e que devem ser também qualificadas.

Com relação aos Estados Unidos, constata-se que, historicamente, as relações oscilaram em fases de maior aproximação e outras de relativo afastamento. Apesar de sua importância (obviamente maior para o Brasil), e à despeito dessas oscilações, não se pode dizer que chegaram a configurar-se em parceria estratégica no sentido aqui propugnado. Principalmente por haverem sido marcadas por divergências em torno de temas considerados, a seu tempo, e por cada país, fundamentais para a consecução de seus respectivos interesses. É verdadeiro que, no presente, as relações com os Estados Unidos atravessam um muito bom 
momento, apesar das divergências magnificadas pela amplitude e complexidade dos temas que compõem a agenda bilateral e dos interesses que a animam. No entanto, persistem divergências sobre a forma de encaminhar interesses comuns, são ainda suficientemente acentuadas para permitir caracterizar as relações como convergentes a ponto de gerar ou compor uma parceria estratégica. São exemplificativas as divergências em torno do interesse brasileiro no domínio de tecnologias no campo nuclear e aeroespacial, a vinculação de temas como meio ambiente e direitos sociais e comércio internacional e, principalmente, a estratégia de construção da ALCA. Além disso, são marcadamente ambíguas as posições norte-americanas em relação ao Mercosul, precisamente uma das prioridades da política externa brasileira, afora o desequilíbrio comercial e sucessivos conflitos nesse campo.

Não é, em absoluto, o propósito aqui reificar as divergências entre Brasil e Estados Unidos, mas apenas assinalar que as mesmas estão estabelecidas em torno de temas de grande importância para o desenvolvimento brasileiro, o que, por sua vez, não reduz, em nenhum sentido, a importância e a prioridade assignada às relações bilaterais; por outro lado, as linhas de convergência de interesses estão definidas em torno de grandes questões da agenda internacional, cujo tratamento se dá, sobretudo, em outras instâncias multilaterais nas quais o sentido de parceria estratégica entre ambos países se dilui em um conjunto maior de alinhamentos que a tornam virtualmente inoperante nesse plano. Esses fatores nos parecem ser significativos o suficiente para desqualificar o sentido de parceria estratégica, tal como considerado no presente trabalho.

No entanto, independentemente da caracterização que se possa dar às relações do Brasil com os Estados Unidos, a sua incidência sobre o Mercosul tende a ser definida, em grande medida, pela maior ou menor margem de convergência entre ambos países nos temas comerciais a nível bilateral, regional e multilateral e pelos termos em que se definir a competição por mercados em âmbito regional. A esse respeito, deve-se tomar em conta que os interesses econômicos brasileiros estão hoje muito dirigidos à América do Sul por ser esta não apenas um mercado crescente (cerca de $25 \%$ das exportações), mas por ser aquele mercado no qual as exportações de bens manufaturados continuam a expandir-se, contrariamente do que ocorre em outras regiões.

Nesse sentido, a perspectiva da ALCA, enquanto projeto político e estratégico dos Estados Unidos, não deve ser desconsiderada em seus desdobramentos potenciais para o modelo de desenvolvimento de forma geral e para as políticas industrial e de comércio exterior do Brasil e dos países do Mercosul, além, obviamente, do potencial de conflito já claramente evidenciado durante a fase preparatória que culminou com a II Cúpula das Américas de abril de 1998. Esse potencial, no entanto, parece ter sido mitigado com a prevalência dos termos 
defendidos pelos países do Mercosul, liderados pelo Brasil, e pela decisão de serem as negociações co-presididas em sua fase final por Brasil e Estados Unidos, cada qual com poder de veto. Ainda assim, não há incentivos, para o Brasil, que justifiquem, nas atuais circunstâncias, exercer qualquer tipo de unilateralismo dentro desse contexto, e nem tampouco de buscar qualquer forma de relacionamento com os Estados Unidos que implique o enfraquecimento do Mercosul. Assim, o Brasil está obrigado a atuar dentro de uma margem muito estreita e de um delicado equilíbrio de interesses econômicos que envolve suas próprias leituras e objetivos nacionalmente definidos, aqueles definidos e concertados regionalmente e aqueles direcionados ao aproveitamento, em conjunto com os demais sócios do Mercosul, de possibilidades que um melhor relacionamento com os Estados Unidos pode suscitar, mesmo que não exclusivamente restritas a aspectos econômicos.

As relações com a União Européia, por sua vez, têm sido marcadas por uma crescente diversificação de interesses no plano econômico. Outrora muito centradas nos principais países (Alemanha, França e Inglaterra), atualmente contemplam, de modo mais intenso, outros pólos, não se circunscrevendo apenas ao campo comercial. Há importantes iniciativas no plano dos investimentos que têm produzido uma crescente diversificação quanto à origem de fluxos de capital para o Brasil. O destaque, nesse sentido, recai sobre os países da Península Ibérica que, até 1995, detinham participação muito modesta nos fluxos de investimentos para o Brasil, tendo a ampliado significativamente: basta tomar em conta que o estoque de investimentos de Portugal e Espanha no Brasil, até 1995, atingia US\$ 360 milhões, tendo os investimentos diretos por eles realizados nos últimos dois anos atingido cerca de US\$ 2 bilhões, ou seja, cerca de cinco vezes mais do que aquele valor, sem considerar ainda as participações na privatização de empresas de telecomunicação ${ }^{48}$. Tendência semelhante é observada em relação aos Países Baixos. Ao mesmo tempo, dos três principais países acima mencionados, apenas a França aumentou de forma significativa seus investimentos no Brasil, chamando atenção o declínio da participação relativa da Alemanha nesse contexto, apesar de manter-se, ainda, como terceira principal origem de investimentos diretos para o Brasil, dados os grandes investimentos realizados em décadas anteriores.

Esse tendência de diversificação quanto a origem e destinos dos fluxos de capital começa a projetar-se, embora em ritmo obviamente menos intenso, também no plano comercial. A União Européia absorve 30\% das exportações brasileiras, sendo ainda a Alemanha o principal destino, seguida de Países Baixos, Itália, França e Reino Unido ${ }^{49}$. No entanto, observa-se o aumento da participação relativa destes últimos, e, embora em patamares menores, dos países ibéricos como destino das exportações brasileiras ${ }^{50}$. No tocante às importações, observa-se um panorama semelhante: $27 \%$ das importações brasileiras procedem da União Européia. Dentre os dez principais países de origem das importações brasileiras em todo o mundo, cinco pertencem à UE: Alemanha, Itália, França, Reino Unido e Espanha. 
Em conjunto, esses fatos significam que alteraram-se as condições que, no passado, permitiram ao Brasil a opção de manter relacionamento privilegiado com um país, a Alemanha, apesar de esta ainda apresentar-se como principal parceiro individual para o Brasil na União Européia. O Brasil é, hoje, levado a considerar a maior diversidade de vínculos econômicos com os países daquela região, fato que se fortalecerá à medida em que avance o processo de integração européia, por um lado, e aprofunde-se o Mercosul, por outro. No que se refere aos seus desdobramentos para o Mercosul, há que se notar, em primeiro lugar, que tal tendência reforça, de modo geral, o sentido de valorização do relacionamento interblocos, não somente por ratificar a importância recíproca de ambos blocos nos planos comercial e financeiro, mas também porque fortalece um capital político importante para o Mercosul e que deve ser tomado em conta tanto nas relações com a própria União Européia, como também em relação a outros contextos de negociação. Em segundo lugar, há que se observar que a maior presença dos países ibéricos nas relações do Brasil com a União Européia também representa um fator positivo e que reforça tendência, já observada desde a admissão destes à então Comunidade Econômica Européia, de atuarem no sentido de promover maior aproximação com a América Latina, fator este que seguramente será de particular relevância quando efetivamente tiverem início as negociações visando a criação de área de livre-comércio entre Mercosul e União Européia, a partir de 1999, como se espera.

Por outro lado, cabe indagar se o incremento das relações econômicas do Brasil com a União Européia implica risco de desvio de comércio e de investimentos em desfavor de seus sócios no Mercosul. Nesse sentido, há que se observar que o fortalecimento dessas relações vem sendo orientado fundamentalmente por força das oportunidades comerciais e financeiras e pela lógica da ação empresarial, e não por instrumentos preferenciais que pudessem ocasionar tais desvios. O impulso político que vem sendo imprimido pelo governo brasileiro se dá no sentido de gerar condições facilitadoras de negócios, e de buscar melhores condições de acesso ao mercado europeu, o que não representa, per se, risco de alienar os interesses dos demais sócios do Mercosul. Ademais, o relacionamento econômico a nível bilateral tende a ser cada vez mais condicionado e a refletir-se no diálogo político que vem sendo arquitetado a nível inter-regional, e que teve como marco recente mais importante a Cúpula Mercosul-União Européia ocorrida ao final do primeiro semestre de 1999.

Portanto, a natureza estratégica das relações com a União Européia, além da intrínseca importância econômica, encontra-se hoje estreitamente vinculada ao sentido associativo que possa permitir entre o Mercosul e aquele bloco e ao capital político que elas podem aportar para negociações inter-regionais e em outros foros regionais ou multilaterais. Muito desse sentido estratégico vem sendo também 
delineado nos cada vez mais freqüentes diálogos em nível político conduzidos por meio do Grupo do Rio com a União Européia, e que conformam uma agenda muito ampla integrada por temas tradicionais como diálogo político, comércio, investimentos, mas que incorpora também novos temas no diálogo inter-regional como segurança e educação ${ }^{51}$. A ampliação desse diálogo em torno de tal sorte de temas revela a preocupação da União Européia de também exercer um papel mais protagônico na região com o sentido de preservar seus interesses face a um percebido intento de parte dos Estados Unidos de estabelecer mecanismos de acesso privilegiado ao mercado latino-americano, o que abre possibilidades para o Brasil e para o Mercosul de exercitarem conjuntamente uma política que vise melhores níveis de equilíbrio entre seus interesses e os de seus respectivos parceiros no mundo industrializado, notadamente os Estados Unidos. Trata-se, enfim, de uma parceria que tende a incorporar a dimensão inter-regional, afastando-se do padrão vigente em décadas anteriores, e, nesse sentido, mais favorável em termos de oportunidades e implicações para o Mercosul.

Com o Japão, o Brasil vem procurando revigorar a parceria construída ao longo das últimas quatro décadas. Isso porque, tanto no plano comercial quanto no financeiro, constata-se estarem as relações aquém de sua potencialidade. No entanto, é no campo dos investimentos que observa-se mais nitidamente a retração da presença japonesa: apesar de ainda deter um estoque de investimento que o coloca como o principal investidor no Brasil, o fluxo de investimentos japoneses para o Brasil vem reduzindo-se. Essa tendência reflete o amadurecimento de investimentos realizados em setores industriais, como a siderurgia, e no setor agroindustrial em décadas anteriores e a maior dispersão dos investimentos em relação a outros países em desenvolvimento, com ênfase àqueles situados no próprio contexto asiático; reflete, por fim, a dificuldade de ambos governos, em redefinir o conteúdo econômico de suas relações em face das oportunidades suscitadas com o advento do Mercosul, a abertura e estabilização da economia brasileira e com o processo de privatização em curso. A essa dificuldade, somaram-se, nos últimos anos, outras que afetaram projetos bilaterais importantes, a exemplo do Programa de Desenvolvimento Agrícola dos Cerrados, a persistência de obstáculos de acesso ao mercado japonês, sobretudo de produtos agrícolas, e, mais recentemente, a própria crise da economia japonesa que, seguramente, incidirá nos fluxos comerciais e financeiros com o Brasil.

Em que pese os fatores que dificultam o fortalecimento da parceira com o Japão, há, no entanto, oportunidades que, ao serem perseguidas bilateralmente, podem estender-se ao Mercosul. A primeira delas decorre precisamente do fato de estar-se redefinindo e revigorando os termos dessa parceria quando consolidase a união aduaneira do Mercosul, tornando-o uma variável fundamental e indeclinável nesse contexto; em segundo lugar, porque, ao avaliar-se possibilidades 
de intensificar as relações bilaterais, alguns setores, como a agroindústria em vários de seus segmentos, biotecnologia, eletrônica e informática, tendem a ser priorizados, abrindo possibilidades de buscar conjuntamente melhores condições de acesso ao mercado japonês e de estabelecimento de parcerias comerciais, financeiras e tecnológicas mais abrangentes e que envolvam também atores econômicos dos demais países do Mercosul.

No plano dos países em desenvolvimento, são enunciadas como prioritárias as relações com China, Índia e África do Sul. A pretendida parceria com a China reveste-se efetivamente de caráter estratégico, pelo que representa aquele país em termos econômicos e políticos no plano regional e global, em sua projeção presente e futura, como também pelo sentido de complementaridade de interesses em áreas importantes para o desenvolvimento brasileiro. Trata-se, no entanto, de relacionamento cujas bases econômicas estão ainda aquém de seu potencial, embora venham expandindo-se, no plano comercial, particularmente nos últimos anos. Somado a isso, há igualmente uma estreita cooperação técnico-científica que envolve setores tradicionais, mas que abarca setores de ponta, como atividades aeroespaciais, com destaque, nesse âmbito, para a construção e lançamento de satélites de comunicação e de monitoramento ambiental, o primeiro deles ocorrido em outubro de 1999, segmento que abre, aos dois países, amplas oportunidades econômicas, mas que é, ao mesmo tempo, objeto de acirrada concorrência internacional.

As relações sino-brasileiras, no entanto, seguem condicionadas, sobretudo, aos desdobramentos das reformas econômicas chinesas e das oportunidades que estas possam suscitar para a diversificação e aprofundamento dos laços econômicos com o Brasil, mas encerram, também, grande potencial de projeção e realização de interesses brasileiros na Ásia. No entanto, diferentemente do que ocorre com relação aos países antes mencionados, não são claras suas implicações para o Mercosul, uma vez que seu encaminhamento tem se dado tendo por referência os interesses bilaterais, não estando, ao mesmo tempo, a China ainda incorporada efetivamente à agenda externa do Mercosul. No entanto, não há razões para admitir que a construção de parceria com a China não venha a ter o mesmo sentido de convergência com os interesses do Mercosul, a exemplo dos casos anteriores.

Diferentemente, as relações com a África do Sul já estão claramente enquadradas nessa perspectiva, e revestem-se de sentido estratégico pelo que implicam em termos de aproximação do Mercosul com a África Austral, incluindo os países da SADECC, como também enquanto componentes de construção e manutenção de estabilidade política e estratégica no Atlântico Sul. A visita do Presidente Nelson Mandela ao Brasil e à Argentina, e sua participação na Cúpula dos Presidentes do Mercosul realizada em Ushuaia, Argentina, são sinalizadoras da disposição política no sentido da construção dessa parceria. Suas bases 
econômicas, tanto do ponto de vista comercial quanto de investimentos, são ainda, no entanto, modestas. Portanto, por suas afinidades culturais, sociais e políticas, $o$ Brasil deve desempenhar um papel chave na construção do relacionamento entre Mercosul e os países da África Austral, e, em particular com a África do Sul.

Em relação à Índia, há um conjunto de elementos de convergência que, até o momento, não foram traduzidos em resultados econômicos efetivos. Assim, apesar do porte de ambas economias e de sua diversificação, das dimensões de mercado e de também terem iniciado o processo de abertura econômica no mesmo período, o comércio bilateral é pequeno. Ainda assim, e em que pese a disposição política dos respectivos governos de aprofundarem as relações tanto no campo econômico como no da cooperação científica e tecnológica, há uma forte susceptibilidade a considerações de ordem política decorrentes, sobretudo, da instabilidade que marca o relacionamento da Índia com o Paquistão e, consequentemente, das posições assumidas pela Índia no tocante à proliferação nuclear. Assim como ocorre em relação à China, a agenda com a Índia tem sido construída fundamentalmente a partir dos interesses definidos em termos bilaterais, embora haja o interesse e a percepção, por parte do governo indiano, da importância e do potencial do Mercosul. No entanto, são ainda frágeis as bases de interesses privados que possam dar substância, no campo econômico, ao relacionamento com o Mercosul. Isso coloca, ao mesmo tempo, a oportunidade, para este, de buscar desenvolver um trabalho conjunto de promoção de oportunidades comerciais e de investimentos, e de cooperação científica e tecnológica, e de, simultaneamente, racionalizarem seus esforços de presença naquele mercado.

Finalmente, no âmbito latino-americano, é importante a referência à Venezuela, país com o qual o Brasil vem incrementando relações nos últimos anos com base em um conjunto de projetos de grande relevância estratégica para o país, sobretudo nas áreas de infra-estrutura, energia e meio ambiente, e que assumem particular significado no contexto da aproximação do Brasil com seus vizinhos ao norte e com o Grande Caribe, e do Mercosul com o Pacto Andino. Apesar da instabilidade que acomete a economia venezuelana, e também de vicissitudes internas relacionadas à implementação das reformas políticas introduzidas pelo Presidente Hugo Chávez, os dois países vêm empreendendo intenso esforço no sentido de dinamizar seus vínculos bilaterais com base em interesses concretos. Estes referem-se, do lado brasileiro, ao desenvolvimento de uma política ativa no contexto amazônico, voltada para o desenvolvimento regional e para o exercício de controle efetivo sobre seu território e sobre os fluxos de contrabando e narcotráfico, atendendo, ao mesmo tempo, necessidades de suprir oferta energética e infra-estrutura viária e de comunicação e na geração de bases para o desenvolvimento sustentável da região; na perspectiva venezuelana, apresenta-se a possibilidade de ampliar e diversificar exportações e de aceder ao mercados 
brasileiro e dos demais países do Mercosul de forma eficiente, de explorar o potencial econômico de atividades que ensejem o desenvolvimento sustentável de seu território amazônico, como o ecoturismo, e de gerar condições de estabilidade nas áreas fronteiriças, evitando a evasão e a degradação de recursos naturais, e, em particular, dos recursos hídricos da cabeceira do Rio Orenoco.

Em razão desses esforços, as relações econômicas passaram a exibir indicadores positivos: a corrente de comércio vem crescendo sustentadamente desde 1992, tendo atingido, em 1998, cerca de US $\$ 2,5$ bilhões, com déficit comercial para o Brasil, determinado, em grande medida, pelas compras de petróleo: cumpre destacar ser, no presente, a Venezuela, ao lado da Argentina, o principal fornecedor ao Brasil. O grande desafio que se coloca, em termos de parceria estratégica, associa-se à diversificação dos fluxos comerciais e a alavancagem de investimentos, por um lado, e de dar operacionalidade à efetiva aproximação, no plano econômico, entre o Mercosul e o Pacto Andino. Sem que este último aspecto seja adequadamente atendido, perder-se-á muito do sentido estratégico que se identifica nas relações com a Venezuela, embora haja um componente associado à problemática amazônica que inevitavelmente o seguirá definindo.

\section{Conclusões}

A construção de parcerias estratégicas pelo Brasil tem assumido, em diferentes contextos, um caráter instrumental para a promoção do desenvolvimento do país, constituindo-se a partir de interesses e oportunidades definidas em cada caso, sem caráter excludente e, portanto, dentro da perspectiva universalista que caracteriza a política externa brasileira. A funcionalidade e o conteúdo dessas alianças não estão definidos de forma estática; pelo contrário, respondem mais às mudanças no contexto interno e externo e ao modelo de desenvolvimento a que servem, e menos a considerações de ordem ideológica e cultural.

Trata-se, portanto, de uma estratégia versátil e orientada por um sentido de oportunidade, de caráter realista e pragmático. Por essa razão, é possível identificar, ao longo da evolução histórica da política externa brasileira, diferentes formas de parcerias definidas segundo a natureza dos interesses em jogo, dos sócios mesmos e das circunstâncias internacionais: aquelas indutoras do desenvolvimento, como as que envolvem os países do Primeiro Mundo; aquelas voltadas para a sustentação do desenvolvimento, como as estabelecidas, sobretudo, com países em desenvolvimento; e formas mistas.

Nesse sentido, suas implicações para o Mercosul devem ser consideradas a partir de condições específicas, considerando o grau de convergência entre as prioridades a que se vinculam e aquelas definidas pelos demais sócios do Mercosul, com particular ênfase à Argentina. De forma geral, o esforço brasileiro no sentido 
de reforçar e diversificar parcerias não é incompatível com a prioridade conferida ao aprofundamento do Mercosul; ao contrário, abre possibilidades importantes em termos das relações externas do bloco.

No entanto, não o fazem de modo automático. Isso ocorrerá à medida em que exista uma sólida base de convergência entre os países do Mercosul em torno de prioridades nas relações com os países vizinhos e com regiões com as quais tais parcerias sejam consideradas importantes para a realização dos interesses de cada país e do próprio bloco. Não se trata, evidentemente, de uniformizar políticas externas, senão de estabelecer formas de coordenação que permitam maximizar esforços e que sejam, ao mesmo tempo, suficientemente flexíveis para resguardar os interesses e necessidades de cada país, sem desqualificar os compromissos recíprocos no âmbito do Mercosul.

A agenda externa cada vez mais ampla do Mercosul, ao lado do sentido mais participativo que a formulação da política externa vem assumindo em cada país, ratifica e nutre a demanda por maior coordenação de posições no plano externo, o que coloca para o Brasil o grande desafio de harmonizar, de um lado, a vocação universalista de sua política externa e o interesse de resguardar relativa margem de autonomia na construção de parcerias e, de outro, os requerimentos de coordenação e de equilíbrio que devem fundamentar a dinâmica do Mercosul e suas relações com seus sócios nesse mesmo âmbito.

Ao mesmo tempo, a tendência no sentido de que as parcerias sejam cada vez mais estruturadas tanto em âmbito bilateral como inter-regional implica a necessidade de melhor coordenação entre as ações que cada país conduz em nível bilateral com os objetivos definidos regionalmente. Nesse sentido, o processo de negociação entre o Mercosul e a União Européia constitui uma oportunidade para definir linhas de convergência entre os países membros que se projetem para além do âmbito comercial, uma vez que tal negociação, ainda que estabelecida em torno de temas relacionados a um regime de livre-comércio, traz importantes conseqüências desde o ponto de vista político, uma vez que sinaliza a disposição de parte do Mercosul de manter um conjunto equilibrado de vínculos externos e de extrair os benefícios que estes possam aportar.

No mesmo sentido, as negociações no âmbito da ALCA deverão fortalecer o perfil comunitário do Mercosul frente a seus interlocutores no continente. O que é necessário avaliar doravante é em que medida esses avanços estarão também refletidos na disposição e nas possibilidades de parte de cada país do Mercosul, e sobretudo do Brasil, de incorporar o âmbito comunitário aos distintos eixos bilaterais que conformam opções de parcerias estratégicas no presente. 


\section{Notas}

1 Texto apresentado no seminário “Integración y seguridad en el Mercosur + Chile”, Universidad Torcuato di Tella, Buenos Aires, 07 e 08 de setembro de 1998. O autor agradece os comentários e sugestões dos Professores Fernando Augusto Albuquerque Mourão, Antônio Carlos Lessa e Amado Luiz Cervo.

2 Celso L.N. Amorim, "Uma diplomacia voltada para o desenvolvimento e a democracia", em FONSECA Jr., Gelson e NABUCO DE CASTRO, Sérgio H. Temas de Política Externa Brasileira II, vol. I, 2 ed. São Paulo: FUNAG/Paz e Terra, p. 16.

3 Para uma discussão conceitual do tema, ver Rubens Antônio Barbosa e Luis Fernando Panelli César, "O Brasil como Global Trader", em FONSECA Jr, Gelson e NABUCO DE CASTRO, Sérgio Henrique, op. cit., vol. I , p. 285-304.

4 LESSA, Antônio Carlos. "A diplomacia universalista do Brasil: a construção do sistema contemporâneo de relações bilaterais”. Revista Brasileira de Política Internacional, ed. Especial, julho de 1998, p. 30.

5 Amado Luiz Cervo, "Relações Internacionais do Brasil", em CERVO, Amado L. (org.), $O$ Desafio Internacional. Brasília: UnB, 1994, p. 28.

6 A respeito, ver Amado Luiz Cervo, op. cit., p. 31-50.

7 Ver SATO, Eiiti. “40 anos de política externa brasileira, 1958-1998: três inflexões”. Revista Brasileira de Política Internacional, ed. Especial, julho de 1998, p. 8-28. Sato aponta o abandono dos Estados Unidos como eixo pivotal da política externa do Brasil, a ampliação das opções de parcerias internacionais e a crescente importância do multilateralismo como as principais inflexões ocorridas no período.

8 Antônio Carlos Lessa, op. cit., p. 36.

9 Amado Luiz Cervo, op. cit., p. 26-27.

10 Antônio Carlos Lessa, op. cit., p. 31.

11 Idem.

12 Lessa argumenta que a universalidade provê uma válvula de escape em situações em que há estreitamento das margens de atuação e decisão em razão da dinâmica do próprio sistema, como no caso de crises, da incapacidade de obtenção de insumos para o desenvolvimento por meio dos relacionamentos tradicionais ou da deterioração das relações políticas e econômicas com a potência hegemônica. No mesmo sentido, enxerga funcionalidade de parcerias estratégicas em situações de exacerbação da competição por recursos e influência. Op. cit., p. 32.

13 TUCHMAN, Barbra, A marcha da insensatez: história e política externa de 1500 a 1975. São Paulo: Ed. Campus, 1987.

14 Rubens Ricúpero, “O Brasil, a América Latina e os Estados Unidos desde 1930: 60 anos de uma relação triangular”, em GUILHON DE ALBUQUERQUE, José A (org.), Sessenta anos de política externa brasileira: 1930-1990, crescimento, modernização e política externa. São Paulo: Cultura Editores Associados, 1996, p. 44.

15 Rubens Ricúpero, op. cit., p. 45.

16 Na formulação de Amado L. Cervo, "o nacionalismo determinava os fins da política e o pragmatismo lhe confiava os meios multiplicados: esse era o esquema." Amado L. Cervo, op. cit., p. 43.

17 Amado Luiz Cervo, op. cit., p. 47.

18 A expressão "hegemonia cêntrica e autonomia periférica" foi cunhada por Hélio Jaguaribe para descrever o contexto externo e o interesse de afirmação de autonomia que orientavam a política externa brasileira na segunda metade dos anos setenta e primeira metade dos anos oitenta. Ver: JAGUARIBE, Hélio. A América Latina e o Cenário Internacional. Rio de Janeiro, 1985. 
19 As relações com a Alemanha tiveram como marco o Tratado de Comércio e Navegação de 1827 e foram intensificadas a partir da unificação alemã em 1871 e com a migração de colonos alemães para o Brasil, o que favoreceu um intenso intercâmbio também no campo cultural posteriormente. Para uma análise histórica das relações teuto-brasileiras, ver MENEZES, Albene M. e KOTHE, Mercedes. Brasil e Alemanha: 1827 -1997: Perspectivas Históricas. Brasília: Thesaurus, 1997. Francisco Thompson-Flores Netto, “As Relações Brasil-Alemanha”, em FONSECA Jr., Gelson e CASTRO, Sérgio N., op. cit., p 105.

Banco Central do Brasil. Censo de Capitais Estrangeiros no Brasil, ano-base 1995. Nos últimos dois anos, registrou-se declínio do fluxo de capitais alemães para o Brasil, apesar do processo de privatização em curso, o que explica-se fundamentalmente pela intensa demanda por investimentos na ex-Alemanha Oriental a partir da reunificação, bem como pelo próprio processo de privatização alemão.

Francisco Thompson-Flores Netto, op. cit., p. 110.

Banco Central do Brasil. Censo de Capitais Estrangeiros no Brasil, ano-base 1995.

Secretaria de Comércio Exterior. Balança Comercial Brasileira, 1997.

Henrique Altemani de Oliveira, "O Brasil e o Japão nos anos 90", em FONSECA Jr. Gelson e NABUCO DE CASTRO, Sérgio H., op. cit., p. 175.

Luis Augusto P. Souto Maior. "O Pragmatismo Responsável”. GUILHON DE ALBUQUERQUE, José op. cit., p. 337-338.

Antônio Carlos Lessa, op. cit., p. 31.

28 Essa expressão foi freqüentemente empregada, durante os Governos Geisel e Figueiredo, para caracterizar o papel a que o Brasil se dispunha, em contraposição a qualquer sentido de liderança ou hegemonia que pudesse fomentar ou acentuar desconfianças já presentes em seus vizinhos e acentuar o propósito cooperativo que orientava a política externa para a região. Luiz Augusto Souto Maior, op. cit., p. 346.

30 Daí o estancamento do processo de integração regional no âmbito da ALALC e, posteriormente, da ALADI nos anos oitenta, bem como de iniciativas de caráter regional como o Tratado de Cooperação Amazônica de 1978.

31 Luis Felipe Seixas Corrêa, "A política externa do Governo Sarney”, in GUILHON DE ALBUQUERQUE, op. cit., p. 370.

32 Cumpre lembrar que o comércio intra-regional crescera, na segunda metade dos anos setenta e início dos anos oitenta, a taxas superiores que o comércio internacional.

33 São importantes, nesse sentido, o reatamento de relações com Cuba, o papel que o Brasil passou a desempenhar no Grupo de Apoio ao processo de Contadora e, subseqüentemente, no Grupo do Rio, e a intensa diplomacia presidencial conduzida na região. A propósito, ver Luis Felipe S. Corrêa, op. cit., p. 370-373.

34 Pelo lado do Brasil, foram característicos os esforços frustrados dos governos de Dutra, e, já no período autoritário, de Castelo Branco, e, em menor medida, de Garrastazu Médici no início dos anos setenta.

35 Mônica Hirst e Letícia Pinheiro. "A política exterior do Brasil em dois tempos”. Revista Brasileira de Política Internacional, 38 (1), p. 6. Marcos C. de Azambuja. A politica externa do Governo Collor, citado em HIRST, Mônica e PINHEIRO, Letícia, op. cit., p. 7. Ver Celso Lafer, "Perspectivas e possibilidades da inserção internacional do Brasil", Política Externa, vol 1, n. 3, dez. 1992, p. 117.

38 Celso Lafer, Ministro das Relações Exteriores durante os meses finais do Governo Collor, referia-se às forças centrífugas e centrípetas atuando no sistema internacional.

39 Cumpre recordar que a desgravação tarifária no âmbito do Mercosul se deu em ritmo mais intenso que a abertura comercial para com as demais regiões. 
40 Segundo as palavras do então Chanceler Celso Amorim, "a agenda diplomática deve mesclar de forma cuidadosa elementos de continuidade e de inovação e evitar as guinadas abruptas, ditadas por conversões precipitadas ou descabidos sentimentos de rejeição, que por vezes chegam à auto-rejeição. Sem assumir o que de fato somos - país em desenvolvimento, pluriracial e com enormes desafios a vencer, nos planos social, econômico e tecnológico - não lograremos alcançar as condições e os instrumentos necessários à superação de nossos problemas e a uma inserção internacional adequada”. Discurso no Instituto Rio Branco em 16 de março de 1994.

41 São exemplos de tais iniciativas as propostas de criação da Área de Livre-Comércio da América do Sul (ALCSA) e a Iniciativa Amazônica.

42 Mônica Hirst e Letícia Pinheiro, op. cit., p. 19.

43 Esse período coincidiu com a etapa final da Rodada Uruguai e com a transição para a Organização Mundial do Comércio, com o retorno do Brasil ao Conselho de Segurança, além de outras iniciativas de âmbito multilateral como a Conferência de Teerã sobre Direitos Humanos.

44 Luis Felipe Lampreia, discurso proferido no Fórum Nacional em maio de 1998.

45 Idem.

46 Idem.

47 Idem.

48 Banco Central do Brasil, op. cit., p.19-20.

49 Deve-se observar que grande parte das exportações brasileiras destinadas à União Européia entra pelo Porto de Roterdã, o que faz com que os valores das exportações para a Holanda sejam muito elevados, uma vez que o registro das estatísticas brasileiras toma em conta o porto de desembarque, e não o destino final das mercadorias.

50 A Alemanha absorve 5,8\%, os Países Baixos (inclusive Holanda) 11\%, a Itália 4,3\%, a França $2,2 \%$ e o Reino Unido $2,5 \%$ do total das exportações brasileiras em geral.

51 VIII Reunião Interministerial UE-Grupo do Rio. Documento de Base, fevereiro de 1998.

\section{Resumo}

O texto analisa a conformação de parcerias dentro do amplo contexto da política exterior do Brasil, enfatizando seus aspectos bilaterais e sua relação com o Mercosul.

\section{Abstract}

The article analyses the conformation of partnerships inside the broader context of Brazilian foreign policy, emphasizing its bilateral aspects and their relation to Mercosur.

Palavras-chave: Brasil. Parcerias estratégicas. Key-words: Brazil. Strategic partnerships. 